\title{
THE EFFECT OF PUGUNTANO (CURANGA FEL-TERRAE [LOUR.]) EXTRACT ON ADIPONECTIN RECEPTOR (ADIPOR) IN RATS WITH TYPE 2 DIABETES MELLITUS
}

\author{
DHARMA LINDARTO ${ }^{1 *}$, YETTY MACHRINA ${ }^{2}$, SANTI SYAFRIL ${ }^{1}$, AWALUDDIN SARAGIH ${ }^{3}$
}

${ }^{1}$ Department of Internal Medicine, Faculty of Medicine, Universitas Sumatera Utara, Indonesia. ${ }^{2}$ Department of Physiology, Faculty of Medicine, Universitas Sumatera Utara, Indonesia. ${ }^{3}$ Department of Biology Pharmacy, Faculty of Pharmacy, Universitas Sumatera Utara Medan, Indonesia. Email: dharma@usu.ac.id

Received: 27 October 2018, Revised and Accepted: 14 December 2018

ABSTRACT

Objective: This study aimed to determine whether the antidiabetic effects of puguntano (Curanga fel-terrae [Lour.]) extract involve anti-inflammatory effects mediated through adiponectin receptors (AdipoRs).

Methods: Type 2 diabetes mellitus (T2DM) Wistar rats were induced by a combination of high-fat diet for 5 weeks and injection small dose streptozotocin $30 \mathrm{mg} / \mathrm{kg}$ bw/rat. This study was conducted in $48 \mathrm{~T} 2 \mathrm{DM}$ rats, which were randomly assigned into two weight-matched groups $(\mathrm{n}=24$, each). Only the treatment group received $0.2 \mathrm{mg} / \mathrm{g}$ bw of puguntano extract suspension through oral for 10 days. The clinical characteristics of T2DM and AdipoR were assessed before and after the treatment period.

Results: The treatment group demonstrated significantly lower body weight, fasting blood glucose, and homeostasis model assessment-insulin resistance (HOMA-IR) but higher AdipoR than the control group (all, p<0.001). Furthermore, there were also negative correlations between AdipoR to body weight and HOMA-IR (all, p<0.05).

Conclusion: Our data suggest that puguntano could improve glucose metabolism and ameliorate insulin resistance and have anti-inflammatory effects mediated through AdipoR in T2DM.

Keywords: Type 2 diabetes mellitus, Puguntano, Adiponectin receptor.

(C) 2019 The Authors. Published by Innovare Academic Sciences Pvt Ltd. This is an open access article under the CC BY license (http://creativecommons. org/licenses/by/4. 0/) DOI: http://dx.doi.org/10.22159/ajpcr.2019.v12i2.30456

\section{INTRODUCTION}

Diabetes mellitus (DM) is a progressive chronic metabolic disease characterized by the presence of hyperglycemia due to impaired insulin secretion, resistance to insulin on tissues, or a combination of both [1]. Various epidemiological studies have shown an increasing trend in the prevalence of type 2 DM (T2DM) in various parts of the world, including Indonesia. In Indonesia, the International Diabetes Federation has predicted that there will be an increase in the number of T2DM patients from 10.3 million (2017) to 16.7 million (2045). Furthermore, Indonesia is one of the three countries with the largest number of 20-79-year-old people with impaired glucose tolerance and the forerunner of T2DM, alongside China and the United States [2].

There has been evidence showing that diabetes is an inflammatory disease. Type 1 DM (T1DM) is characterized by autoimmune-mediated destruction of pancreatic $\beta$-cells [3], and T2DM is now being redefined as an immune disorder [4]. Adiponectin is an anti-inflammatory adipokine secreted by adipocytes. Adiponectin has received attention due to its involvement in interactions between adipocytes and other metabolically active tissues $[5,6]$. In addition, it is known as an insulin sensitizer in the target tissues in vivo [7], and it suppresses inflammatory responses. Several studies show that the administration of adiponectin increases fatty acid oxidation in skeletal muscle, suppresses lipid accumulation in the liver, increases muscle insulin sensitivity $[8,9]$, and suppresses gluconeogenesis [10], which involves the activation of adenosine monophosphate-activated protein kinase. A previous study about the effect of adiponectin on lipid metabolism found that it prevented lipolysis through the activation of hormone-sensitive lipase and suppression of protein kinase A activity [11]. Another study showed that exercise can promote the expression of adiponectin mRNA and GLUT4 mRNA in Type 2 diabetic rats, which may be one of the mechanisms responsible for the amelioration of insulin resistance in the rats [12].

The effects of adiponectin are mediated through Type 1 and 2 adiponectin receptors (AdipoR1 and AdipoR2) [13]. AdipoR1 is expressed in skeletal muscle and liver while AdipoR2 is predominantly expressed in the liver. Although these receptors are structurally similar (66\% homology), AdipoR1 has a high affinity for adiponectin, whereas AdipoR2 has a moderate affinity [14]. In the genetically obese rat model, the expression of both AdipoR1 and AdipoR2 decreases in the liver, but the improvement expression of one of these receptors would improve the whole-body metabolism [8].

The boiled leaves of puguntano (Curanga fel-terrae [Lour.]) become a traditional medicine, which is believed to have antidiabetic activity. Puguntano is a plant from the Scrophulariaceae family, and it has been used as medicine by people in Tiga Lingga village, Dairi Regency, North Sumatra Province of Indonesia. In addition, the plant is also believed to be efficacious for pain relief, to increase endurance, and as an anti-aging agent. The plant is, therefore, widely cultivated by the local community for its medicinal effects [15].

In a preliminary clinical trial, the administration of puguntano extract for 12 weeks to patients with newly diagnosed T2DM was found to be more effective in reducing the level of fasting blood glucose (FBG), HbA1c, and homeostasis model assessment-insulin resistance (HOMA-IR) and increasing plasma adiponectin than metformin $(p<0.05)[16]$.

The purpose of this study was to evaluate whether AdipoR increases alongside plasma adiponectin if diabetic rats are administered puguntano extract. 


\section{METHODS}

\section{Animals}

Adult Wistar rats aged 8 weeks and weighing 180-200 g were selected. They were divided into two groups (24 rats/group) through a simple random sampling in which one group was the control group, and the other was the treatment group. The rats were fed a normal diet for 3 days. They were then fed with a high-fat diet for 5 weeks, and multiple low-dose streptozotocin injections (30-45 mg/kg bw/rat) were administered to T2DM model. The rats were maintained at a temperature of $27 \pm 2^{\circ} \mathrm{C}$ under a $12 \mathrm{~h} / 12 \mathrm{~h}$ light/dark cycle (lights on from 07:00 to 19:00 h) [17].

\section{Plant materials}

Puguntano plants were collected from Dairi area in North Sumatra Province, Indonesia. The plant has been used for the treatment of diabetes empirically by brewing the leaves of puguntano. Puguntano extract was produced by maceration method using $70 \%$ ethanol [18] and administered orally as a suspension at $0.2 \mathrm{~g} / \mathrm{g}$ bw/day for 10 days to the treatment group. The study was conducted at the Laboratory of the Research Unit, Faculty of Medicine, Padjadjaran University. The experimental design has been approved by the Ethics Committee for Research on Health in the Faculty of Medicine.

\section{Collection of blood samples}

Blood samples were collected from the lateral tail vein of the rats. At the end of the experiment (day 10), the rats were anesthetized by diethyl ether before being sacrificed due to exsanguination. The abdomen and thorax were opened immediately, and blood was collected through cardiac puncture using sterile syringes and needles. Fasting plasma insulin was determined using an enzyme-linked immunosorbent assay (ELISA) kit while AdipoR was determined with rat AdipoR 1 ELISA. HOMA-IR was assessed using a standard formula: Fasting insulin $(\mu \mathrm{U} / \mathrm{ml}) \times$ fasting glucose $(\mathrm{mg} / \mathrm{dl}) / 22.5$ [19].

\section{Statistical analysis}

Data were expressed as mean and standard deviation. The difference between mean values before and after the treatment was evaluated within each group using Student's paired t-test. To compare the two groups, independent (unpaired) Student's t-test and Spearman's rank-order correlation were used. All data were analyzed using SPSS version 22.0. A level of significance $(\alpha)$ of 0.05 was used in the study.

\section{RESULTS}

The fasting blood sugar (FBG) and body weight of the two groups were similar before the induction of diabetes (Table 1).

Table 1: Body weight and FBG of rats before the induction of T2DM

\begin{tabular}{llll}
\hline Variable & $\begin{array}{l}\text { Group 1 }(\mathbf{n}=\mathbf{2 4}) \\
\text { Mean } \pm \text { SD }\end{array}$ & $\begin{array}{l}\text { Group 2 (n=24) } \\
\text { Mean } \pm \text { SD }\end{array}$ & p \\
\hline Body weight $(\mathrm{g})$ & $209.70 \pm 6.57$ & $215.66 \pm 37.44$ & 0.634 \\
FBG (mg/dl) & $77.79 \pm 6.80$ & $75.08 \pm 7.55$ & 0.282 \\
\hline
\end{tabular}

Data are expressed in median (minimum-maximum) and mean \pm SD, categorical data are expressed in number of subjects (n); Group 1: Control group; Group 2: Treatment group, FBG: Fasting blood glucose, T2DM: Type 2 diabetes mellitus, SD: Standard deviation
However, FBG and body weight of the control and treatment groups before and after the induction of T2DM were significantly different $(\mathrm{p}<0.001)$ (Table 2).

Body weight, FBG, HOMA-IR, and AdipoR were significantly different between the control group and the puguntano-treated group (Table 3).

In addition, there was a significant negative correlation found between AdipoR with body weight and HOMA-IR, but a positive significant correlation was found between AdipoR and plasma insulin across all T2DM rats (all, $\mathrm{p}<0.05$ ) (Table 4).

\section{DISCUSSION}

Molecules secreted by adipocytes, termed as adipokines, and have been shown to affect the whole-body metabolism and energy homeostasis. One of these, adiponectin has received significant attention as a mediator of insulin sensitivity. Many studies have demonstrated lower circulating levels of adipokines in humans and animal models of obesity, insulin resistance, and T2DM [20,21]. Furthermore, adiponectin administration can prevent maximal glucose production, even in the presence of subphysiological plasma insulin levels.

Medicinal plants tend to produce primary and secondary metabolites that have different roles [22]. The primary metabolites consist of amino acids, simple sugar, amino acid, proteins, and lipids, whereas the secondary metabolites contain active chemical groups (including flavonoids, alkaloids, terpenoids, steroids, and saponins)andare producedin response to stress. The secondary metabolites have more complex structures and more restricted distribution than the primary metabolites [23]. Ethanol extract of puguntano leaves obtained using the maceration methods contains the same phytochemicals, namely flavonoids, saponins, tannins, glycosides, and steroids/terpenoids [24]. Similarly, mahkota dewa fruit (Phaleria macrocarpa) has strong anti-inflammatory effects because it contains a similar mixture of terpenoids, saponins, tannins, flavonoids, phenols, and catechols [25].

The present study found that the administration of puguntano extract suspension significantly decreased body weight, FBG, and HOMA-IR but increased AdipoR in puguntano-treated T2DM rats compared to the control rats. These findings are consistent with the results of a previous study, in which 7-week administration of green coffee bean extract could decrease FPG, profile lipid, and blood pressure and improved adiponectin level and HOMA-IR index [26]. In addition, diabetic rats treated with Haematococcus pluvialis extract showed significant improvement in oxidative stress, enhanced antioxidant status, and inflammatory cytokines induced by hyperglycemia in diabetic rats [27]. These results imply that the treatment with puguntano may improve glucose metabolism and ameliorate insulin resistance and inflammation through adiponectin and AdipoR in patients with T2DM.

Moreover, the study results also showed that AdipoR was inversely correlated with body weight, FBG, and HOMA-IR. It means that higher AdipoR is associated with higher insulin sensitivity and normal glucose metabolism, whereas lower AdipoR is associated with higher insulin resistance and abnormal glucose metabolism. These findings are also in accordance with the previous studies regarding that lower adiponectin level is associated with insulin resistance and development of T2DM [28], and the assumption that adiponectin

Table 2: Body weight and FBG of rats before and after the induction of T2DM

\begin{tabular}{|c|c|c|c|c|c|c|}
\hline \multirow[t]{2}{*}{ Variable } & \multicolumn{3}{|c|}{ Body weight $(g)(n=24)$, Mean \pm SD } & \multicolumn{3}{|c|}{ FBG $(\mathrm{mg} / \mathrm{dl})(\mathrm{n}=24)$, Mean $\pm S D$} \\
\hline & Before & After & $\mathbf{p}$ & Before & After & $\mathbf{p}$ \\
\hline Group 1 & $209.70 \pm 6.57$ & $386.33 \pm 20.92$ & $0.001^{* *}$ & $77.79 \pm 6.80$ & $355.12 \pm 7.55$ & $0.001^{* *}$ \\
\hline Group 2 & $215.66 \pm 37.44$ & $368.25 \pm 26.65$ & $0.001^{* *}$ & $75.08 \pm 7.55$ & $252.41 \pm 43.92$ & $0.001^{* *}$ \\
\hline
\end{tabular}

Data are expressed in median (minimum-maximum); categorical data are expressed in number of subjects (n), Group 1: Control, Group 2: Treatment. FBG: Fasting blood glucose; p-values are for a single group before and after induction of diabetes: **: $\mathrm{p}<0.001$, T2DM: Type 2 diabetes mellitus, SD: Standard deviation 
Table 3: Comparison of parameters between groups after treatment with puguntano extract solution

\begin{tabular}{llll}
\hline Variable & $\begin{array}{l}\text { Group 1 (n=24) } \\
\text { Mean } \pm \text { SD }\end{array}$ & $\begin{array}{l}\text { Group 2 (n=24) } \\
\text { Mean } \pm \text { SD }\end{array}$ & $\mathbf{p}$ \\
\hline Body weight (g) & $386 \pm 20.92$ & $245.54 \pm 35.54$ & $0.001^{* *}$ \\
FBG (mg/dl) & $355.12 \pm 105.65$ & $136.62 \pm 33.62$ & $0.001^{* *}$ \\
Insulin (mIU/L) & $57.36 \pm 6.28$ & $52.32 \pm 3.32$ & $0.001^{* *}$ \\
HOMA-IR & $3.05 \pm 0.51$ & $0.86 \pm 0.20$ & $0.001^{* *}$ \\
AdipoR (ng/ml) & $13.79 \pm 1.48$ & $16.64 \pm 3.83$ & $0.001^{* *}$ \\
\hline
\end{tabular}

Data are expressed in median (minimum-maximum); categorical data are expressed in number of subjects (n); Group 1: Control, Group 2: Treatment, FBG: Fasting blood glucose, HOMA-IR: Homeostasis model assessment-insulin resistance, AdipoR: Adiponectin receptor, ${ }^{* *}$ : $\mathrm{p}<0.001$, SD: Standard deviation

Table 4: Correlations between AdipoR and other variables in T2DM rats

\begin{tabular}{lll}
\hline Variable & $\mathbf{r}$ & $\mathbf{p}$ \\
\hline Body weight $(\mathrm{g})$ & -0.85 & 0.041 \\
FBG $(\mathrm{mg} / \mathrm{dl})$ & -0.12 & 0.127 \\
Insulin $(\mu \mathrm{U} / \mathrm{ml})$ & 0.91 & 0.024 \\
HOMA-IR & -0.88 & 0.033 \\
\hline
\end{tabular}

Data are expressed in Spearman's rank-order correlation, FBG: Fasting

blood glucose, HOMA-IR: Homeostasis model assessment-insulin resistance,

T2DM: Type 2 diabetes mellitus

may play an important role in the pathogenesis of abnormal glucose metabolism [29].

\section{CONCLUSION}

The administration of puguntano leaves ( $C$. fel-terrae [Lour.]) ethanol extract can improve glucose metabolism, ameliorate insulin resistance, and inflammation in T2DM. Furthermore, higher AdipoR was inversely correlated with insulin resistance (HOMA-IR).

Further study is recommended to investigate the active substances present in puguntano leaves which are responsible for these effects.

\section{ACKNOWLEDGMENT}

Authors would like to thank the Ministry of Research, Technology, and Higher Education (Kemenristekdikti) for providing funding to the present research.

\section{AUTHORS' CONTRIBUTIONS}

DL and YM designed the study. DL and SS conducted the experiments. DL and AS determined the plant model and analyzed the data. DL, YM, and SS wrote the manuscript and discussed it with AS. All authors read and approved the final manuscript.

\section{CONFLICTS OF INTEREST}

The authors report that there were no conflicts of interest when writing the manuscript.

\section{REFERENCES}

1. Chaudhury A, Duvoor C, Reddy Dendi VS, Kraleti S, Chada A, Ravilla R, et al. Clinical review of antidiabetic drugs: Implications for type 2 diabetes mellitus management. Front Endocrinol (Lausanne) 2017;8:6.

2. International Diabetes Federation. IDF Diabetes Atlas. $8^{\text {th }}$ ed. International Diabetes Federation; 2017.

3. Graham KL, Sutherland RM, Mannering SI, Zhao Y, Chee J, Krishnamurthy B, et al. Pathogenic mechanisms in type 1 diabetes: The islet is both target and driver of disease. Rev Diabet Stud 2012;9:148-68.

4. Tsai S, Clemente-Casares X, Revelo XS, Winer S, Winer DA. Are obesity-related insulin resistance and type 2 diabetes autoimmune diseases? Diabetes 2015;64:1886-97.

5. Scherer PE. Adipose tissue: From lipid storage compartment to endocrine organ. Diabetes 2006;55:1537-45.

6. Deng Y, Scherer PE. Adipokines as novel biomarkers and regulatorsm of the metabolic syndrome. Ann NY Acad Sci 2011;1226:50.

7. Berg AH, Combs TP, Du X, Brownlee M, Scherer PE. The adipocytesecreted protein Acrp30 enhances hepatic insulin action. Nat Med 2001;7:947-53.

8. Yamauchi T, Nio Y, Maki T, Kobayashi M, Takazawa T, Iwabu M, et al. Targeted disruption of adipoR1 and adipoR2 causes abrogation of adiponectin binding and metabolic actions. Nat Med 2007;13:332-9.

9. Yamauchi T, Kamon J, Minokoshi Y, Ito Y, Waki H, Uchida S, et al. Adiponectin stimulates glucose utilization and fatty-acid oxidation by activating AMP-activated protein kinase. Nat Med 2002;8:1288-95.

10. Combs TP, Berg AH, Obici S, Scherer PE, Rossetti L. Endogenous glucose production is inhibited by the adipose-derived protein Acrp30. J Clin Invest 2001;108:1875-81.

11. Qiao L, Kinney B, Schaack J, Shao J. Adiponectin inhibits lipolysis in mouse adipocytes. Diabetes 2011;60:1519-27.

12. Tang Z, Yuan L, Gu C, Liu Y, Zhu L. Effect of exercise on the expression of adiponectin mRNA and GLUT4 mRNA in type 2 diabetic rats. J Huazhong Univ Sci Technolog Med Sci 2005;25:191-3, 201.

13. Kiezun M, Maleszka A, Smolinska N, Nitkiewicz A, Kaminski T. Expression of adiponectin receptors 1 (AdipoR1) and 2 (AdipoR2) in the porcine pituitary during the oestrous cycle. Reprod Biol Endocrinol 2013;11:18

14. Blüher M, Williams CJ, Klöting N, Hsi A, Ruschke K, Oberbach A, et al. Gene expression of adiponectin receptors in human visceral and subcutaneous adipose tissue is related to insulin resistance and metabolic parameters and is altered in response to physical training. Diabetes Care 2007;30:3110-5.

15. Depkes RI. Inventaris Tanaman Obat Indonesia (I). Cetakan Pertama. Jakarta: Departemen Kesehatan RI; 2000b. p. 21-2.

16. Lindarto D, Syafril S, Zein U, Saragih A. The effect of dhawalsan-1 [Curangafel-terrae (lour.)] extract versus metformin on the metabolic and inflammatory characteristics of patients with newly diagnosed type 2 diabetes mellitus. Asian J Pharm Clin Res 2016;9:225-8.

17. Zhang M, Lv XY, Li J, Xu ZG, Chen L. The characterization of high-fat diet and multiple low-dose streptozotocin induced type 2 diabetes rat model. Exp Diabetes Res 2008;2008:704045.

18. Depkes RI. The Ministry of Health Republic of Indonesia. Inventory of Indonesia Medical Plant (1). First print. Jakarta: RI Ministry of Health; 2000b. p. 21-2.

19. Matthews DR, Hosker JP, Rudenski AS, Naylor BA, Treacher DF, Turner RC, et al. Homeostasis model assessment: Insulin resistance and beta-cell function from fasting plasma glucose and insulin concentrations in man. Diabetologia 1985;28:412-9.

20. Pajvani UB, Scherer PE. Adiponectin: Systemic contributor to insulin sensitivity. Curr Diab Rep 2003;3:207-13.

21. Maeda N, Shimomura I, Kishida K, Nishizawa H, Matsuda M, Nagaretani $\mathrm{H}$, et al. Diet-induced insulin resistance in mice lacking adiponectin/ACRP30. Nat Med 2002;8:731-7.

22. Croteau R, Kutchan TM, Lewis NG. Natural products (secondary metabolites). In: Buchanan B, Gruissem W, Jones R, editors. Biochemistry and Molecular Biology of Plants. Rockville, MD: American Society of Plant Physiologists; 2000. p. 1250-318.

23. Keeling CI, Bohlmann J. Genes, enzymes and chemicals of terpenoid diversity in the constitutive and induced defence of conifers against insects and pathogens. New Phytol 2006;170:657-75.

24. Harahap U, Patilaya P, Marianne YS, Husori Di PB. Phytochemical Profile of Ethanol Extract of The Puguntano Leaf (Curanga Fel-Terrae [Lour].) which has Potential as Anti-asthma. National Seminar On Science \& Technology V, Research Institute Of Lampung University; 2013.

25. Hendra R, Ahmad S, Oskoueian E, Sukari A, Shukor MY. Antioxidant, anti-inflammatory and cytotoxicity of Phaleria macrocarpa (Boerl.) scheff fruit. BMC Complement Altern Med 2011;11:110.

26. Lukitasari M, Nugroho DA, Rohman MS, Nugrahini NI, Sardjono TW. Light-roasted green coffee extract improved adiponectin, insulin resistance, and metabolic profile of metabolic syndrome rat model. Asian J Pharm Clin Res 2017;9:279-83.

27. El-Baz FK, Aly HF, Khalil WK, Ali GH, Hafiz NA, Saad SA. Potential role of Haematococcus pluvialis against diabetes induced oxidative stress and inflammation in rats. Asian J Pharm Clin Res 2017;1:245-51.

28. Tan CH, Dakis MK, Reyes CL, Ki DY, Langcamon SJ, Magdamit DT, et al. Adiponectin as a biomarker of type 2 diabetes mellitus. Int J Sci Res Publ 2015;5:1-4

29. Ahsan S, Ahmed S, Ahmed SD, Nauman K. Status of serum adiponectin related to insulin resistance in prediabetics. J Pak Med Assoc 2014;64:184-8. 